\title{
The effect of chlorhexidine on the colour and tint change of ceramic dental veneer
}

Dorota Klimecka-Tatar, Stanisław Borkowski

Czestochowa University of Technology, Faculty of Management, Institute of Engineering Production, Armii Krajowej 19b, 42-200, Częstochowa,e-mail:klimt@wip.pcz.pl

Frequent consumption of certain products contained the different kinds of chemical compounds affects on the colour of teeth, especially on prosthetic restoration timbre. A very interesting issue is to determine the effect of exposure in some of the commonly used chemical substances on dental restorations colour change. The study was conducted on the upper crown of the tooth, namely the first incisor. The colour evaluation change has been made using a spectrophotometer SpectroShade, which determines the amount of light absorbed by the element over the entire visible spectrum $380-720 \mathrm{~nm}$. In the paper was shown that long-term use of products that contain chlorhexidine can lead to permanent color change of ceramics dental materials. After long exposure in the solution the ceramic became lighter but their hue value indicates that the color is closer to yellow.

Keywords: dental veneer, colour change, spectrophotometer, dental restoration

\section{References}

[1] HATTAB F.N., QUDEIMAT M.A., AL-RIMAWI H.S. (1999) Dental discoloration: an overview, Journal of Esthetic Dentistry pp. 11-13.

[2] JOINER A. (2004) Tooth colour: a review of the literature, Journal of Dentistry. Vol. 32, pp. 3-12.

[3] TERRY D.A., GELLER W., TRIC O., ANDERSON M.J., TOURVILlE M., KOBASHIGAWA A. (2002) Anatomical form defines color: function, form and aesthetics, Practical Procedures and AestheticDentistry Vol. 14, pp. 9-67.

[4] JOINER A., JONES N.M., RAVEN S.J. (1995) Investigation of factorsinfluencing stain formation utilizing an in situ model, Advances in Dental Research, Vol. 9, pp. 471-476.

[5] MACPHERSON L.M.D., STEPHEN K.W., JOINER A., SCHAFER F., HUNTINGTON E. (2000) Comparison of a conventional and modified tooth stain index, Journal of Clinical Periodontology Vol. 27, pp. 854-859.

[6] PRIEST G., LINDKE L. (2000) Tooth color selection and characterisation accomplished with optical mapping, Practical Periodontics and Aesthetic Dentistry, Vol. 12, pp. 497-503.

[7] HAMMAD I.A. (2003) Intrarater repeatability of shade selections with two shade guides, Journal of Prosthetic Dentistry Vol. 89, pp. 50-53.

[8] KHAN A.S., WONG F.S.L., MCKAY I.J., WHILEY R.A., REHMAN I.U. (2013) Structural, mechanical, and biocompatibility analyses of a novel dental restorative nanocomposite Journal of Applied Polymer Science 127 (1), pp. 439-447.

[9] KAYA G. (2013) Production and characterization of self-colored dental zirconia blocks Ceramics International 39 (1), pp. 511-517.

[10] ÇELEN, S., ÖZDEN, H. (2012) Laser-induced novel patterns: As smart strain actuators for new-age dental implant surfaces Applied Surface Science 263 , pp. 579-585.

[11] YI W., HU X., ICHIM P., SUN X. (2012) Processing and properties of pressable ceramic with non-uniform reinforcement for selective-toughening Materials Science and Engineering A 558 , pp. 543-549.

[12] KLIMECKA-TATAR D., BALA H., SLUSAREK B., JAGIELSKA-WIADEREK K. (2009) The effect of consolidation method on elctrochemical corrosion of polymer bonded Nd-Fe-B type magnetic material, Archives of Metallurgy and Materials, Vol. 54, Issue 1, pp. 247-256.

[13] BÍLEK O., ROKYTA L., ŠIMONÍK J. (2012) CAM in the Production of Casting Patterns Manufacturing Technology, Vol. 12, pp. 7-12. 